Monica Reichenberg

Institutionen för pedagogik och specialpedagogik

Göteborgs universitet

E-post: monica.reichenberg@ped.gu.se

\title{
Attityder till innehåll och delaktighet i val av läroböcker i undervisning i svenska för invandrare: \\ Den pedagogiska och didaktiska betydelsen av flyktingars utbildning och yrkesbakgrund
}

\section{Sammandrag}

De senaste åren har fler flyktingar än någonsin anlänt till Skandinavien. De flyktingar som kommit är inte någon homogen grupp. Medan en del av dem är högutbildade kan andra vara analfabeter.

Det övergripande syftet med denna studie är att undersöka relationen mellan humankapital (ålder, tid i Sverige, utbildning) och vuxna flyktingars attityder till innehåll i läroböcker och deras möjligheter att påverka val av läroböcker. I studien ingår 186 vuxna personer som fått fylla i en enkät. Studien ger stöd åt humankapitalteorin, dvs. antalet utbildningsår har betydelse för elevernas attityder till (a) delaktighet vid val av läroböcker och (b) innehållet i läroböcker. Däremot har varken ålder eller tid i Sverige betydelse. Vidare fanns det en relation (om än osäker) mellan socioekonomisk klass och attityder till delaktighet, där en skillnad i medelvärden mellan elever med bakgrund i övre medelklassyrken skilde sig jämfört med elever med bakgrund i arbetarklassyrken.

Resultaten har en tydlig didaktisk och pedagogisk signifikans. Teoretiskt bidrar resultaten till att bekräfta den växande forskningen om betydelsen av humankapitalfaktorer vid studiet av vuxna flyktingars lärande och integration.

Nyckelord: immigration, attityder, delaktighet, läroböcker, humankapital, innehåll

\section{Abstract}

The Scandinavian countries currently face their largest ever influx of refugees. These refugees are far from a homogenous group. Some are highly educated whereas some are illiterate. The purpose of this study was to investigate how human capital (age, length of residence in Sweden, years of education) is associated with adult refugees' attitudes to the contents of Swedish language textbooks and their possibilities to influence which textbooks might be used in their language training programme. 
Using survey data collected from 186 adult refugees. The study lends support to human capital theory. Years of education had a relationship with the refugees' attitudes to possibilities for selecting textbooks based on the content of the textbook (i.e. "childish" or "boring"). Age and length of stay of residence in Sweden had no relationship with the refugees' attitudes.

Theoretically, the results contribute to support the increasing research about the significance of human capital theory when studying refugees' learning and integration. The results also have didactic and pedagogical implications as the study contributes to showing how education and socioeconomic class had relationship with students' attitudes towards textbooks.

Keywords: immigration, attitudes, participation, human capital, textbooks, content

\section{Inledning}

Under de senaste åren har fler flyktingar än någonsin anlänt till Skandinavien. Flyktingar som varit utsatta för såväl emotionella som finansiella påfrestningar såsom förlust av hem, besparingar, familjemedlemmar, vänner som inte kunde komma med och sist men inte minst avbrott i studier och förlust av den säkerhet det innebär att ha ett arbete (United Nations, 2015).

De flyktingar som kommer är inte någon homogen grupp (jfr Lindberg, 2004; Rambøll, 2011). Medan en del av dem är högutbildade kan andra vara analfabeter (Vinogradov \& Bigelow, 2010). ${ }^{1}$

I Sverige erbjuds flyktingarna - såväl högutbildade som analfabeter - kostnadsfri språkträning på särskilda program, Undervisning i svenska för invandrare (SFI). Undervisningen syftar till att vuxna invandrare ska få möjligheter att nå grundläggande kunskaper i svenska språket. Utbildningen syftar också till att ge vuxna invandrare som saknar grundläggande läs- och skrivfärdigheter möjlighet att förvärva sådana färdigheter.

För alla flyktingar innebär det en stor utmaning att lära sig ett nytt språk, men särskilt stor är utmaningen för dem som inte haft möjlighet att delta i skolundervisning under uppväxten eller vars modersmål inte har ett skriftspråk (Vinogradov \& Bigelow, 2010).

En annan stor utmaning är själva undervisningen. Många av flyktingarna har sannolikt erfarenheter av mer traditionell lärarstyrd katederundervisning där läraren har stor auktoritet. Det är läraren som bestämmer hur undervisningen ska utformas och vilka läroböcker som ska väljas. Att komma till Skandinavien och mötas av en undervisning där eleverna förväntas vara aktiva och delaktiga i såväl själva undervisningssituationen som vid val av läroböcker kan säkert te sig som en stor utmaning för många (jfr Rong \& Preissle, 2008; Askeland, 2014; Rambøll, 2011; Storeng, 2001; Hilt, 2016). En utmaning är det också för de som 
inte har gått i skolan och är analfabeter. Icke desto mindre är det varje lärares uppdrag att fostra till delaktighet - att inspirera eleverna att påverka sin utbildning (Schweisfurth, 2011).

Att nyanlända elever direkt skall vara aktiva och delaktiga behöver inte nödvändigtvis vara något den enskilde läraren eftersträvar, utan elevers delaktighet är ett mål som lärare förväntas undervisa utifrån kursplanen för SFI (Skolverket, 2012; Hilt, 2016). Det finns ett pedagogiskt dilemma mellan vad kursplaner föreskriver och vad som är genomförbart (Schweisfurth, 2011). Många av eleverna som har erfarenheter av ett auktoritärt skolsystem kan känna sig osäkra och vill kanske helst avstå från att delta.

Det är därför viktigt att inte "skynda på” med att få eleverna att aktivt delta. Att skola in elever som vuxit upp i ett auktoritärt skolsystem till att bli delaktiga i undervisningen är en process som måste få ta tid (Schweisfurth, 2011; Storeng, 2001). Målen i kursplanen för SFI är dock tydliga att elever ska vara delaktiga. I vad mån lärare följer kursplanen och tillåter vuxna flyktingar att vara delaktiga och därmed kunna vara med och påverka val av läroböcker och "tycka till” om innehållet i dem, finns inte mycket forskning.

Den forskning som finns har i huvudsak uppmärksammat hur lärare väljer läromedel till skolelever (Selander \& Skjelbred, 2004; Juuhl, Hontvedt \& Skjelbred, 2010; Reichenberg, 2014). Vidare har det visat sig att forskningen så gott som uteslutande endast efterfrågat vad lärare tycker om innehållet i läromedel (Bueie, 2002; Skjelbred, Solstad \& Aamotsbakken, 2005; Aamotsbakken \& Skjelbred, 2010). Ett undantag är Justviks studie (2012) där såväl elever som lärare ingick. Justvik fann att skolorna inte gjorde systematiska undersökningar avseende elevernas synpunkter på de läromedel som användes. Resultaten manar till eftertanke. Det gör också studier av Knecht och Najvarová (2010) samt Dargusch, Persaud och Horsley (2011). En genomgående trend i Knechts och Najvarovás metastudie - där de granskat elevinflytande vid val av läroböcker mellan 1974 och 2007 - var att eleverna ville ha intressanta, tydliga och begripliga böcker. Dargusch, Persaud och Horsleys (2011) studie visade att elever som gick i femte och sjätte klass hade potentialer att komma med synpunkter såväl på språklig tillgänglighet som innehåll. I dagens klassrum finns många elever som inte vare sig begriper vad som står i läromedlen eller som anser att innehållet är tråkigt. Det finns också elever som tycker att innehållet är barnsligt och inte åldersadekvat.

Den kvantitativa forskning som finns om utbildning i svenska för vuxna invandrare har sällan intresserat sig för attityder utan mest för beteende- och faktavariabler med hjälp av STATIV - en longitudinell databas för integrationsstudier (SCB, 2014).

I likhet med Knecht och Najvarová (2010) och Dargusch, Persaud och Horsley (2011) är jag helt övertygad om att elever kan bidra med viktig kunskap inte bara till dem som skriver läroböcker utan också för att utvärdera en läroboks didaktiska effektivitet. Följande studie utgör därför ett viktigt bidrag då den vill 
undersöka vuxna flyktingars attityder till (= vad de tycker om) innehållet i läroböckerna och deras delaktighet vid val av läroböcker.

Studien ingår som en del $\mathrm{i}$ en större studie som är en utvärdering av “Utbildning i svenska för invandrare” på ett lärcenter i Sverige.

\section{Syfte och forskningsfrågor}

Det övergripande syftet är att undersöka relationen mellan humankapital (ålder, tid i Sverige, utbildning) och vuxna flyktingars attityder till innehåll i läroböcker och deras möjligheter att påverka val av läroböcker. Utifrån syftet har jag följande två forskningsfrågor:

1. I vilken utsträckning tycker vuxna flyktingar att de får vara delaktiga vid val av läroböcker?

2. I vilken utsträckning tycker vuxna flyktingar att innehållet $i$ läroböcker är barnsligt/tråkigt?

Den första frågan motiveras mot bakgrund av den forskning som rör det pedagogiska dilemmat nämligen att många flyktingar kommer från länder med en auktoritär katederundervisning, medan de i Skandinavien möts av en undervisning där de förväntas vara delaktiga och ha en positiv attityd till att vara delaktiga vid bland annat val av läromedel. Den andra forskningsfrågan motiveras av att den forskning som gjorts rörande innehåll i läromedel nästan enkom efterfrågat lärarnas attityder men saknat elevernas. En mer fördjupad beskrivning av forskningsproblemet ges i avsnittet om teoretiskt ramverk och litteraturöversikt.

\section{Avgränsningar}

I Undervisning i svenska för invandrare används olika läromedel. Ett av dem är läroboken. I denna studie har jag valt att endast efterfråga läroboken. Skälet till detta är att läroboken fortfarande är central inom vuxenundervisning även om datorn börjar att användas alltmer. Vid det lärcenter där undersökningen gjordes noterade jag att det låg läroböcker på elevernas bänkar och att de användes i undervisningen även om eleverna också använde dator.

En annan viktig avgränsning är att studien enkom studerar sambandet, dvs. relationen mellan humankapital och vuxna flyktingars attityder till innehåll i läroböcker samt och deras möjligheter att påverka val av läroböcker. Studien gör inga anspråk på att försöka identifiera kausala effekter. Jag återkommer till denna begränsning i slutdiskussionen.

Artikeln har följande disposition: Först diskuterar jag det teoretiska ramverket. Därefter kommer enkätdata och metod. Slutligen presenteras beskrivande 
statistik, variansanalys och Ordinary Least Square-regression. Jag avslutar med en diskussion med möjliga förklaringar till resultaten och hur dessa kan sättas i relation till nuvarande forskning.

\section{Teoretiskt ramverk och litteraturöversikt}

Som nämndes i inledningen är de vuxna flyktingarna som kommer till Sverige inte någon homogen grupp (Nilsson \& Nyström, 2016). Medan en del av dem är högutbildade kan andra vara analfabeter. De skiljer sig med andra ord åt vad mängden av humankapital beträffar (Nilsson \& Nyström, 2016). Humankapitalteorin är bland annat den tid en person investerar i utbildning mätt i antal utbildningsår, men teorin innefattar också ålder och den tid personen har stått till arbetsmarknadens förfogande - $\mathrm{i}$ det här fallet hur länge de har varit $i$ Sverige (Adamuti-Trache, Anisef, Sweet \& Walters, 2013).

I denna studie använder jag följande förklaringsvariabler från humankapitalteorin: utbildningsnivå, ålder och tid i Sverige. Vidare använder jag också kontrollvariablerna socioekonomisk klass i hemlandet ("migration class"), familjestatus och kön. I nedanstående stycke beskriver jag deras relation till studiens två beroende variabler: attityder till delaktighet i valet av nya läroböcker och innehållet i läroböckerna.

\section{Attityder till delaktighet vid val av läroböcker}

Den utbildning flyktingarna har med sig spelar roll även om inte alla får den validerad under den första tiden i Sverige (Nilsson \& Nyström, 2016). Utbildningen rustar dem för att klara den omställning det innebär att möta ett nytt språk, en ny kultur och att bli delaktiga i ett nytt samhälle (Hilt, 2016). De som har en längre utbildning har studievana och har också kommit i kontakt med mycket kurslitteratur. Deltagare med kort eller ingen utbildning har inte så mycket studievana och har sannolikt inte heller mött så många böcker, vilket kan medföra att det blir svårare att tillgodogöra sig undervisningen och ha synpunkter på läroböcker (Lindberg, 2004; Kjelsaas, 2011).

En genomgående trend i tidigare studier är att vuxna invandrare inte tillåts att vara delaktiga. Hvenekilde, Alver, Bergander, Lahaug och Midttun (1996) fann att de vuxna deltagarna inte hade någon möjlighet att få förmedla sina förväntningar på alfabetiseringsläromedlen. I en svensk studie gjord drygt tio år senare fick Franker (2007) liknande resultat, nämligen att lärarna inte efterfrågade de vuxna lågutbildade deltagarnas synpunkter på läromedel. Skaalvik (2004) undersöker visserligen inte delaktighet vid val av läroböcker men menar att vuxna norska andraspråkselever snarare är mottagare än medverkande i undervisningssituationen. Lärarna "handler mer på grunnlag av egne holdninger, verdier og 
selvvurderinger enn ut fra elevenes uttalte behov og ønsker” (Skaalvik, 2004, s. 66; se också Rambøll, 2011).

Jag har endast kunnat finna en studie (Pollestad, 2015) som fann att de vuxna elevernas erfarenheter togs tillvara. Elevernas synpunkter fick till följd att många lärare valde bort läroboken och istället producerade eget material som framgår i citatet nedan:

Det jeg bruker mest, er egenprodusert, sånn at undervisningen kan ta utgangspunkt i deltakerne [...] Hver analfabet trenger på en måte sin egen bok. De kommer fra forskjellige kulturer og de har ulike tempoer/læringsstrategier. (Pollestad, 2015, s. 69)

\section{Attityder till innehåll i läroböcker}

Vid val av läroböcker är det centralt att granska innehållet. Extra viktigt blir detta när man väljer läroböcker till vuxna. Här uppstår två pedagogiska dilemman. Ett första pedagogiskt dilemma uppstår om eleverna ser att deras synpunkter (attityd) till de använda läroböckerna inte tas tillvara; då kommer de sannolikt inte att känna sig delaktiga i undervisningen. Om innehållet däremot bygger på elevernas synpunkter finns möjligheten att de känner sig delaktiga.

Franker (2007) fann att lärarna som undervisade på alfabetiseringskurser valde alltför förenklade bilder därför att de förväxlade elevernas ovana av bildtolkning med oförmåga att tolka bilder. Alver och Dregelid (2001) fann att Første bok på norsk inte bygger på deltagarnas tidigare erfarenheter. Detta var länge den enda bok som fanns att tillgå i undervisningen för vuxna analfabeter.

Ett andra pedagogiskt dilemma är språknivån. En lärobok får inte rent språkligt vara för svår eftersom eleverna har ett mycket begränsat svenskt ordförråd, men den får inte heller vara för lätt. Då finns risken att eleverna uppfattar den som barnslig (inte åldersadekvat) / tråkig (Lundberg \& Reichenberg, 2009; Reichenberg, 2013). Här är det en stor pedagogisk utmaning för lärare att finna en lärobok som dels har ett innehåll som är åldersadekvat och angår vuxna elever, dels ligger på en "rätt” språklig nivå.

\section{Uppsummering om attityder till delaktighet och innehåll}

Tidigare kvalitativ forskning har uppmärksammat att vuxna invandrade elevers synpunkter på undervisning/läromedel ofta lämnas därhän (Franker, 2007; Alver \& Dregelid, 2001).

Återkommande i tidigare kvantitativ internationell forskning om vuxna invandrares lärande är humankapitalteorin. Här tycks i synnerhet utbildningsår och ålder vara nyckelfaktorer när det gäller att förklara olika utfall av delaktighet i det nya landet. I mindre utsträckning har frågan om betydelsen av vuxna flykt- 
ingars yrkesbakgrund stått i fokus, dvs. socioekonomisk klass i hemlandet (migrationsklass). Den socioekonomiska klassen representerar en vuxen elevs specifika yrkesfärdigheter som denne lärt sig i jobbet. Dessa färdigheter kan förstås ur ett humankapitalperspektiv, som tiden man investerat i att lära sig ett yrke. Socioekonomisk klass behöver inte alltid vara synonymt med antal utbildningsår. Det händer att en högutbildad person - med många års utbildning inte nödvändigtvis alltid får ett högkvalificerat arbete. Det kan också vara fallet att en låg till medelutbildad person har lärt sig högkvalificerade arbetsuppgifter på arbetet och mött/möter många texter där (Karlsson, 2006). Vad eleverna lärt sig i sitt yrke kan påverka vad de tycker om innehållet i läroböckerna de använder. Det kan exempelvis medföra att de som haft högkvalificerade yrken (t. ex. jurist, socionom) i högre utsträckning tycker att innehållet är barnsligt jämfört med dem som haft lågkvalificerade yrken (t. ex. garvare, butiksbiträde).

Eftersom delaktighet vid val av läroböcker är en del av lärandet förefaller det rimligt att pröva huruvida humankapitalteorins förklaringsvariabler står sig i denna studie, eftersom teorin är väletablerad med god prediktionsstyrka (Sweetland, 1996). Men variablerna i denna teori räcker inte, därför tillför jag ännu en, nämligen socioekonomisk klass i hemlandet (migration class).

\section{Metod}

\section{Deltagare i studien}

Sedan slutet av 1990-talet har antalet deltagare på utbildningen i undervisning i svenska för invandrare ökat och uppgick 2013 till 113600 deltagare (Skolverket, 2015). Arabiska är det största modersmålet bland deltagarna och Irak, Somalia och Syrien är de vanligaste födelseländerna. Majoriteten av deltagarna är 25-39 år gamla. Det är fler kvinnor än män som går på utbildningen (Skolverket, 2015). Nybörjare 2011 som slutförde minst en kurs med godkänt resultat studerade i genomsnitt i 436 timmar. Tiden mellan start- och slutdatum var i genomsnitt 56 veckor.

I denna studie deltog 186 personer som under 2015 studerade på Götalands lärcenter ${ }^{2}$. Urvalet är inte slumpmässigt. Det beror på att detta är en uppdragsstudie som gjordes med anledning av att rektor för Götalands lärcenter bett vår institution att utvärdera verksamheten. Vidare ville rektor att eleverna skulle vara i fokus. Urvalet är därför deltagarstyrt. Ett sådant urval har både för-och nackdelar. A ena sidan begränsade det deltagarstyrda urvalet möjligheterna att dra slutsatser om studiepopulationens inverkan på måttens representativitet. Å andra sidan innebar det deltagarstyrda urvalet en möjlighet att kunna utvärdera SFI-elevers attityder till läroböcker, vilket är underbeforskat. Att få reda på detta är viktigt eftersom SFI-elevers attityder kan ha tydliga pedagogiska och didaktiska konsekvenser. I syfte att få reda på elevernas attityder konstruerades en enkät. På en skala från 1 till 7 skulle elever göra skattningar (1 = Instämmer inte, 
7 = Instämmer helt). I enkäten ingick också en uppsättning bakgrundsfrågor (t. ex. ålder, kön, utbildning, antal barn etc.).

De flesta av de 186 deltagarna var flyktingar från Syrien, följt av Somalia och Iran/Irak. Endast de elever som studerade i startgruppen - dvs. de elever som läst svenska i bara en eller några veckor och var helt nya på Götalands lärcenter - har utelämnats i studien då det bedömdes att de hade deltagit för kort tid för att kunna ha någon uppfattning om läromedel.

Konfidentialitet är centralt i denna studie. Därför har lärcentret fått ett fingerat namn. Alla deltagare fick information om studiens syfte och de hade möjlighet att tacka nej.

\section{Genomförande}

Den höga andelen analfabeter har inneburit en metodologisk utmaning. Åtskilliga av deltagarna hade aldrig sett en enkät förut än mindre fått liknande frågor som de som ingick i enkäten. Jag var därför noga med att de inte skulle behöva skriva något utan endast ringa in korrekt siffra.

Innan deltagarna fick börja fylla i enkäten hade läraren och jag tillsammans en noggrann genomgång $\mathrm{i}$ alfabetiseringsgrupperna. Deltagarna besvarade en fråga i taget. Vi hade skrivit upp varje fråga på PowerPoint. För att öka validiteten och minska risken för mätfel var studiehandledare - som talade elevernas förstaspråk och svenska - också med och hjälpte till att tolka. Vi gjorde också övningar där man skulle svara på en 1-7 skala. Jag var personligen närvarande när enkäterna delades ut, under tiden som deltagarna fyllde i dem och jag samlade också in enkäterna. Deltagarna hade således möjlighet att fråga om de inte förstod. I de grupper där det inte fanns analfabeter gick vi också igenom frågorna och jag liksom undervisande lärare var med hela tiden. Vi gjorde också här övningar där man skulle svara på en 1-7 skala. Eftersom en del av deltagarna var frånvarande hade vi ett uppsamlingstillfälle. Svarsfrekvensen blev därför hög.

\section{Variabler}

Tabell 1 rapporterar medelvärden, procent, standardavvikelser och min/maxvärden. Som framgår är den "genomsnittlige deltagaren” 35 år gammal och har åtta års utbildning. Den genomsnittlige deltagaren har haft ett arbetarklassyrke i hemlandet (t. ex. garvare, lantarbetare) och har levt i Sverige i två år. Här finns emellertid en viss variation. Utbildningsnivån skiljer sig åt då somliga inte gått $\mathrm{i}$ skola medan andra har 22 års skolgång. Likaså gäller det ålder. Den yngsta deltagaren är 20 år och den äldsta är 65 . Närmare hälften av dem har bott i Sverige en mycket kort tid. Cirka $20 \%$ har haft yrken inom övre medelklass i hemlandet (t. ex. jurister, företagare, ingenjörer) medan $27 \%$ har varit arbetslösa (studenter eller hemmafruar). Det finns lika många män som kvinnor. Vidare hade de studerat i genomsnitt 9 månader på SFI vid denna studies genomförande. 
Tabell 1. Medelvärden och standardavvikelse för beroende- och förklaringsvariablerna i studien.

\begin{tabular}{lllll}
\hline Variabler & $\begin{array}{l}\text { Medelvärde } \\
\text { \& Procent }\end{array}$ & $\begin{array}{l}\text { Standard- } \\
\text { avvikelse }\end{array}$ & Min & Max \\
\hline Beroende variabler: & & & & \\
Läroboken är tråkig & 2.79 & 2.12 & 1 & 7 \\
Läroboken är barnslig & 2.49 & 2.05 & 1 & 7 \\
Delaktighet val & 5.66 & 2.08 & 1 & 7 \\
Index lärobokens innehåll & 5.22 & 3.50 & 2 & 14
\end{tabular}

\section{Humankapitalvariabler:}

Antal utbildningsår i hemlandet

8.14

5.64

0

22

Ålder

34.72

9.27

20

65

Unga (20 till 29 år)

$34 \%$

Medelålders (30 till 39 år)

$36 \%$

Äldre (40 till 65 år)

$30 \%$

Tid i Sverige

2.10

1.78

.3

11

Kort (.3 till 1.4 år)

$45 \%$

Medel(1.4 till 3 år)

$40 \%$

Längre (3.5 till 11 år)

$15 \%$

Socioekonomisk klass i hemlandet

Övre medelklass

$20 \%$

Medelklass

$12 \%$

Arbetarklass

$41 \%$

Arbetslös

$27 \%$

\section{Kontrollvariabler:}

Kön

Män

$52 \%$

Kvinnor

$48 \%$

Familj

$\mathrm{Ja}$

$69 \%$

$\mathrm{Nej}$

$31 \%$

Variabeln för socioekonomisk klass har klassificerats i enlighet med "The European Socio-Economic Classification” som använder ett fyrgradigt klassifikationsschema: salariat, intermediate, working class och unemployed (Rose \& Harrison, 2007). Jag valde detta schema därför att undersökningsgruppen inte var så stor. Exempel på salariat (övre medelklass, min översättning) i denna studie är lärare, jurister, socionomer och ingenjörer. Utmärkande för dessa arbeten är en hög grad av självständighet, yrkesskicklighet och inget rutiniserat jobb. Exempel på medelklassyrken är arbete på kontor, hårfrisör, bagare och 
jordbrukare. Utmärkande för dessa yrken är också självständighet. Exempel på arbetarklassyrken är gruvarbetare och lastbilschaufför. Utmärkande för dessa yrkesgrupper är en inte lika hög grad av självständighet och ofta rutinjobb. Exempel på arbetslösa är hemmafruar och studenter, dvs. personer med en osäker social och ekonomisk position. Ett annat karaktäristika är att gruppen arbetslösa är heterogen - den inrymmer även högutbildade som inte fătt in en fot på arbetsmarknaden i hemlandet. Det gemensamma för gruppen är således att de inte rapporterat arbetslivserfarenhet.

Gruppen analfabeter - hit räknas de som antingen inte gått i skolan alls eller endast gått några få år. De återfinns dels inom arbetarklassyrken, dels bland de arbetslösa. Medan de flesta manliga analfabeterna varit boskapsherdar, garvare, skomakare eller haft en liten affär, hade de flesta kvinnorna varit sysselsatta med hushållsarbete i hemmet.

Att analysera ålder, tid i Sverige och utbildningsår samtidigt kan bidra till problem med kolinearitet, dvs. stark samvariation mellan de oberoende variablerna. Det finns till exempel ett visst samband mellan hur länge man bott $\mathrm{i}$ Sverige och hur länge man levt. Då regressionsanalysen förutsätter att de oberoende variablerna inte har den typen av samband (kolinearitet) måste detta åtgärdas. För att minska problem med kolinjära variabler valde jag därför att koda om ålder och tid i Sverige till kategorivariabler. Följaktligen fanns inga problem vid regressionsdiagnostiken (t. ex. inflation av variansen).

Den första beroende variabeln var elevernas attityd till huruvida läraren bestämde över valet av lärobok, dvs. var eleverna delaktiga $i$ valet? Här indikerar en högre poäng att läraren bestämmer och en lägre poäng att eleverna får vara med och bestämma.

Studiens andra beroende variabel är elevernas attityder till innehållet. För att mäta detta summerade jag två variabler till ett index. Den första variabeln var: "Jag tycker att läroböckerna är tråkiga" och den andra variabeln var "Jag tycker läroböckerna är barnsliga”. En högre poäng på indexet indikerar att eleverna anser att lärobokens innehåll är tråkigt eller barnsligt. Eleverna känner sig antagligen därför inte kognitivt utmanade. En lägre poäng indikerar däremot att läroboken är mer kognitivt utmanande.

För att validera måttet på elevernas attityder till innehållet användes Principiell Komponent Analys (PCA). Något förenklat innebär PCA att man räknar ut "egenvärden" och "egenvektorerna” på en korrelationsmatris för variablerna i fråga. PCA är användbar vid små stickprov med variabler som inte följer en normal fördelning. Hade vi haft en större, slumpmässigt vald undersökningsgrupp hade valet blivit bekräftande faktoranalys.

Ibland används Cronbachs Alfa för att utvärdera komponenter. Cronbachs Alfa används då för att utvärdera reliabiliteten. I strikt mening är Cronbachs Alfa inte ett reliabilitetsmått men det kan fortfarande användas för att göra en grov uppskattning av måttets reliabilitet. Från Tabell 2 framgår att i det här fallet 
var Cronbachs Alfa acceptabelt för lärobokskomponenten (0.58). Här skall dock påpekas att en korrelation mellan variablerna är viktigare än ett högt Alfa-värde.

Tabell 2. Roterad Principiell Komponent Analys.

\begin{tabular}{lll}
\hline Variabel & Lärobokskomponent & Oförklarad varians \\
\hline Läroboken är tråkig & 0.70 & 0.29 \\
Läroboken är barnslig & 0.70 & 0.29 \\
\hline Cronbachs Alfa & 0.58 & \\
\hline
\end{tabular}

\section{Resultat}

Resultatdelen är strukturerad i tre olika steg. I det första steget presenteras en beskrivande analys av medelvärden, standardfel av medelvärdet och konfidensintervallet. I det andra steget genomför jag envägs variansanalys för att se om det finns statistiskt säkerställda skillnader i medelvärdena. Här fokuserar jag på skillnader beroende på utbildningsnivå respektive socioekonomisk klass i hemlandet. I det tredje steget genomför jag två Ordinary Least Squareregressioner. I båda fallen presenteras först humankapitalmodellen och sedan den socioekonomiska klassmodellen samt kontrollvariabler. Standardfelen på medelvärdet har korrigerats eftersom variablerna var snedfördelade vilket ökar chansen att mätfelet inte skulle vara normalfördelat vilket i sin tur kan leda till felaktiga slutsatser. Därför användes s.k. "bootstrapped" standardfel. Det innebär att statistikprogrammet drar upprepade slumpmässiga stickprov 1000 gånger med samma deltagare (dvs. "sampling with replacement”). Med hjälp av dessa upprepade stickprov kan man räkna ut vad det mest frekventa värdet för variansen på medelvärdet varit om man hade upprepat studien 1000 gånger. Denna varians kan räknas om till "bootstrapped” standardfel.

Tabell 3. Medelvärden och standardfelet av medelvärdet för “delaktighet val” respektive "attityd till innehåll” uppdelat efter utbildningsnivå respektive klass.

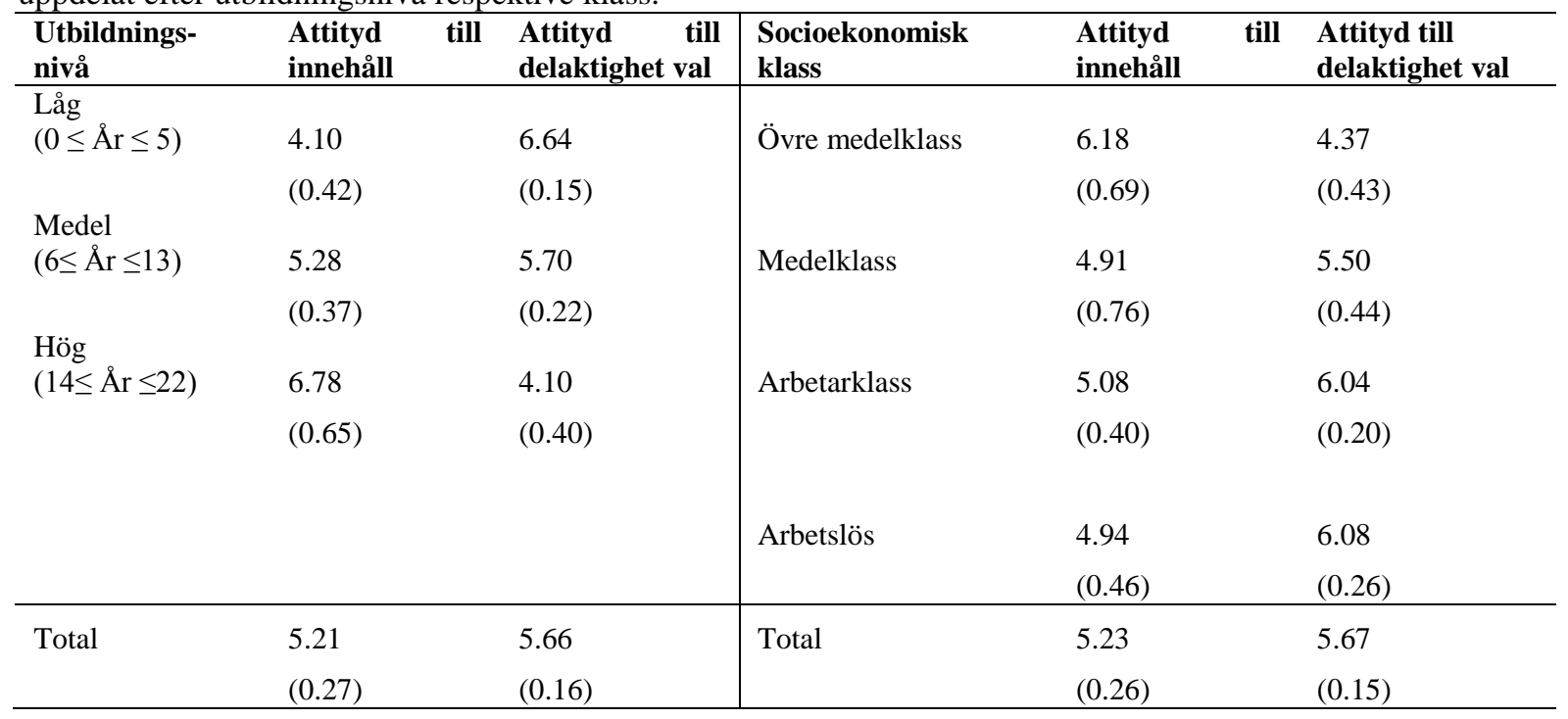


Det första steget: I Tabell 3 ser vi medelvärdet och standardfelet för attityder till delaktighet vid val av läroböcker och innehåll uppdelat efter utbildningsnivå respektive socioekonomisk klass i hemlandet. Vi börjar med attityder till (dvs. vad eleverna tycker om) innehållet. Högre värden indikerar att elever anser att läroböckerna är barnsliga respektive tråkiga. Här är 2 minst och 14 max. Av Tabell 3 framgår att medelvärdet (M) för attityd till innehållet är lägre för lågutbildade än för medelutbildade. Vidare, om vi konstruerar en $95 \%$ konfidensintervall (K.I.) för lågutbildade ( $\mathrm{M}=4.10$, K.I.=3.27; 4.92) respektive medelutbildade $(\mathrm{M}=5.28$, K.I.=4.56; 6.01) kan vi se att de överlappar. Medelutbildade har lägre medelvärde än högutbildade, men här överlappar den $95 \%$ konfidensintervallen ( $\mathrm{M}=6.78$, K.I. $=5.50$; 8.05). Resultaten bör tolkas som att de lågutbildade i lägre utsträckning tycker att innehållet är barnsligt och tråkigt jämfört med medel- och högutbildade. Men vi kan bara vara säkra att det finns en statistisk signifikant skillnad mellan låg- och högutbildade eftersom konfidensintervallerna inte överlappar. Däremot kan vi inte vara säkra på om det finns en signifikant skillnad mellan medelutbildade och det två övriga utbildningskategorierna.

Elever från övre medelklassyrken varierar tydligt $\mathrm{i}$ attityder till lärobokens innehåll (M=6.18, K.I.=4.83; 7.53) liksom elever från medelklassyrken $(\mathrm{M}=4.91$, K.I. $=3.42 ; 6.40)$, då felmarginalerna är något breda på nästan 2 poäng. Båda grupperna anser att läroböckerna i liten utsträckning är barnsliga eller tråkiga. Det finns inte heller några signifikanta skillnader mellan grupperna med avseende på attityder till lärobokens innehåll. Samma mönster återfinns bland elever inom arbetarklassyrken (M=5.08, K.I.=4.30; 5.86) respektive arbetslösa $(\mathrm{M}=4.94$ K.I. $=4.04$; 5.84).

Högutbildade ( $\mathrm{M}=4.10$, K.I.=3.32; 4.89) anser att läraren bestämmer över valet av läroboken i mindre utsträckning än medelutbildade $(\mathrm{M}=5.70$, K.I.=5.27; 6.13) och lågutbildade $(\mathrm{M}=6.64$, K.I.=6.35; 6.93). Ser vi till $95 \%$ konfidensintervallen märker vi att de inte överlappar, vilket indikerar att grupperna skiljer sig signifikant åt. Sammanfattningsvis kan resultaten tolkas som att de lågutbildade anser att läraren ensam bestämmer över val av läroboken. De högutbildade eleverna däremot anser att de får vara med och bestämma.

Ser vi till socioekonomisk klass anser elever från övre medelklassyrken att läraren bestämmer lika mycket som eleverna $(\mathrm{M}=4.37$, K.I.=3.53; 5.21). Elever från medelklassyrken anser däremot att läraren bestämmer något mer. Men skillnaderna är inte signifikanta eftersom konfidensintervallen överlappar $(\mathrm{M}=5.50$, K.I.=4.64; 6.36). Elever från arbetarklassyrken anser att läraren bestämmer för det mesta $(M=6.04$, K.I.=5.65 6.43). Det anser också elever som var arbetslösa i hemlandet ( $\mathrm{M}=6.08$, K.I. $=5.57$; 6.59). Den signifikanta skillnaden här är mellan elever från arbetarklassyrken och övre medelklassyrken, samt mellan arbetslösa och övre medelklassen. Här gäller det dock att inte förglömma att flera högutbildade finns inom gruppen arbetslösa eftersom de inte kommit in på arbetsmarknaden i sina hemländer. Arbetslös är, som jag tidigare 
uppmärksammat, en heterogen kategori med den gemensamma nämnaren att medlemmarna saknar arbetslivserfarenhet.

Det andra steget i analysen var att genomföra en envägs variansanalys (ANOVA). Här korrigerades standardfelen också med bootstrapping. Variansanalysen visade att det fanns en signifikant skillnad i medelvärdena för elever som kom från arbetarklassyrken $(4.2+1.7)$ respektive var arbetslösa $(4.2+1.7)$ i avseende på lärarens inflytande över val av läroboken jämfört med den övre medelklassen (4.2). Effektstorleken låg på $10 \%$. Vidare fanns det inga statistiska skillnader beroende på socioekonomisk klass med avseende på attityd till lärobokens innehåll.

Jämfört med lågutbildade (6.6) ansåg medelutbildade (6.6-.9) och högutbildade (6.6-2.5) att de fick mer inflytande över läroboken. Effektstorleken låg på $19 \%$.

Även vad gäller attityder till lärobokens barnslighets- respektive tråkighetsgrad fanns signifikanta skillnader. Jämfört med lågutbildade (4.1) ansåg medelutbildade $(4.1+1.2)$ och högutbildade $(4.1+2.7)$ att lärobokens innehåll var mer barnsligt respektive tråkigt. Effektstorleken låg på $7 \%$. Här skall man emellertid komma ihåg att skalans maxpoäng är 14, vilket indikerar att man ändå var förhållandevis nöjd med innehållet.

Det tredje steget $\mathrm{i}$ analysen var att se vad som predicerade delaktighet vid val av lärobok. Återigen en högre poäng innebär att läraren bestämmer. I Tabell 4 presenterar jag först variabler från humankapitalmodellen och sedan den socioekonomiska klassmodellen med kontrollvariabler. Den senare modellen kontrollerar också för kön och familjestatus.

En genomgående tendens när det gäller attityd till delaktighet är att yngre elever tycker att läraren bestämmer mer än äldre och medelålders elever. Emellertid är resultaten inte statistiskt signifikanta. Tid i Sverige har ingen effekt och koefficienten är nästan noll. Däremot ser vi att i takt med att antalet utbildningsår ökar, minskar lärarens inflytande över läroboken. Den genomsnittliga effekten av utbildning var 1.4 lägre poäng på attityder till delaktighet. Med andra ord, högutbildade anser att de får mer självbestämmande. Dessa resultat står sig när klass och kön introduceras i modellen. Kön har ingen statistisk betydelse. Däremot anser elever från arbetarklassyrken att läraren bestämmer mer än elever från övre medelklassyrken. Skillnaden är statistiskt signifikant utan korrigerade standardfel. Men efter att standardfelen korrigerats är skillnaden inte längre statistiskt signifikant. Vi bör därför acceptera nollhypotesen om inga skillnader även om det tycks finnas en viss osäkerhet i resultatet. Denna tolkning stärks av att första modellen har en förklarad varians på $19 \%$ och den senare på $21 \%$ vilket är en väldigt liten ökning trots att flera variabler introduceras i modellen. 
Tabell 4. Ordinary Least Square -regression med delaktighet vid val som beroende variabel med prediktorer från humankapitalteorin samt socioekonomisk klass. Icke-standardiserade koefficenter (b) och standardfel i parantes (SE).

\begin{tabular}{|c|c|c|}
\hline $\begin{array}{l}\text { Beroende variabel: } \\
\text { Delaktighet vid val av lärobok }\end{array}$ & $\begin{array}{l}\text { Humankapital- } \\
\text { modellen } \\
\text { b/SE }\end{array}$ & $\begin{array}{l}\text { Socioekonomiska } \\
\text { klassmodellen } \\
\text { b/SE }\end{array}$ \\
\hline \multicolumn{3}{|l|}{ Humankapitalvariabler: } \\
\hline Antal utbildningsår & $\begin{array}{l}-0.172 * * * \\
(0.029)\end{array}$ & $\begin{array}{l}-0.137 * * * \\
(0.039)\end{array}$ \\
\hline \multicolumn{3}{|l|}{ Ålder ${ }^{a}$} \\
\hline Medelålders & $\begin{array}{l}0.134 \\
(0.353)\end{array}$ & $\begin{array}{l}0.242 \\
(0.376)\end{array}$ \\
\hline Äldre & $\begin{array}{l}0.016 \\
(0.364)\end{array}$ & $\begin{array}{l}0.133 \\
(0.433)\end{array}$ \\
\hline \multicolumn{3}{|l|}{ Tid i Sverige ${ }^{b}$} \\
\hline Medel & $\begin{array}{l}-0.494 \\
(0.338)\end{array}$ & $\begin{array}{l}-0.494 \\
(0.330)\end{array}$ \\
\hline Längre & $\begin{array}{l}-0.439 \\
(0.393)\end{array}$ & $\begin{array}{l}-0.419 \\
(0.438)\end{array}$ \\
\hline \multicolumn{3}{|l|}{ Socioekonomisk klass: ${ }^{\mathrm{c}}$} \\
\hline Medelklass & & $\begin{array}{l}0.711 \\
(0.651)\end{array}$ \\
\hline Arbetarklass & & $\begin{array}{l}0.942 \\
(0.527)\end{array}$ \\
\hline Arbetslös & & $\begin{array}{l}0.465 \\
(0.575)\end{array}$ \\
\hline \multicolumn{3}{|l|}{ Kontrollvariabler: } \\
\hline Man & & $\begin{array}{l}-0.335 \\
(0.354)\end{array}$ \\
\hline $\begin{array}{l}\text { Familj } \\
J a\end{array}$ & & $\begin{array}{l}-0.126 \\
(0.350)\end{array}$ \\
\hline Konstant & $\begin{array}{l}7.320 * * * \\
(0.403)\end{array}$ & $\begin{array}{l}6.619^{* * *} \\
(0.726)\end{array}$ \\
\hline $\mathrm{R}^{2}$ & 0.19 & 0.21 \\
\hline
\end{tabular}

${ }^{\mathrm{a}}$ Unga är referenskategorin. ${ }^{\mathrm{b}}$ Kort tid är referenskategorin. ${ }^{\mathrm{c}}$ Övre medelklass är referenskategorin. ${ }^{\mathrm{d}}$ Kvinnor är referenskategorin. ${ }^{\mathrm{e}} \mathrm{Nej}$ är referenskategorin.

*** Signifikant vid $0.1 \%$.

Från Tabell 5 kan vi avläsa att både yngre och äldre elever anser att läroboken varken är tråkig eller barnslig. Medelålders elever tycker däremot att läroboken är något mer tråkig eller barnslig. Skillnaderna är dock inte statistiskt signifikanta. De som levt i Sverige en kort tid tycker att läroboken är mer tråkig eller barnslig än de som levt i Sverige en medel till längre tid. Skillnaderna är inte heller här statistiskt signifikanta. Vad som däremot ger utslag är antal utbildningsår. En genomsnittlig utbildning (dvs. åtta år) ökar attityden barnslig eller tråkig med 1.2 poäng. Denna effekt står sig när man introducerar socioekonomisk klass, kön och familj i modellen. Ingen av dessa tre variabler har någon statistiskt signifikant effekt. Tydligt är dock att arbetarklassyrken i hem- 
landet har en starkare koefficient men osäkerheten indikeras av storleken på standardfelet, dvs. desto högre standardfel desto högre större osäkerhet.

Humankapitalmodellen är således bättre än den socioekonomiska modellen därför att den förstnämnda förklarar mer av variationen i den beroende variabeln, trots en låg förklarad varians på 7 \% jämfört med standard inom utbildningsvetenskap (dvs. runt $20 \%$ till $30 \%$ ). Denna tolkning stärks av att humankapitalmodellen har en förklarad varians på 7 \% och den senare på $9 \%$ vilket är en väldigt liten ökning trots att flera variabler introduceras i modellen.

Tabell 5. Ordinary Least Square -regression med attityder till innehåll som beroende variabel med prediktorer från humankapitalteorin samt klass. Icke-standardiserade koefficenter (b) och standardfel i parantes (SE).

\begin{tabular}{|c|c|c|}
\hline $\begin{array}{l}\text { Beroende variabel: Attityder } \\
\text { till lärobokinnehållet }\end{array}$ & $\begin{array}{l}\text { Humankapital- } \\
\text { modellen } \\
\text { b/SE }\end{array}$ & $\begin{array}{l}\text { Socioekonomiska } \\
\text { klassmodellen } \\
\text { b/SE }\end{array}$ \\
\hline \multicolumn{3}{|l|}{ Humankapitalvariabler: } \\
\hline Antal utbildningsår & $\begin{array}{l}0.154^{* *} \\
(0.055)\end{array}$ & $\begin{array}{l}0.136^{*} \\
(0.064)\end{array}$ \\
\hline \multicolumn{3}{|l|}{ Ålder ${ }^{a}$} \\
\hline Medelålders & $\begin{array}{l}0.210 \\
(0.682)\end{array}$ & $\begin{array}{l}0.288 \\
(0.699)\end{array}$ \\
\hline Äldre & $\begin{array}{l}0.007 \\
(0.678)\end{array}$ & $\begin{array}{l}0.087 \\
(0.721)\end{array}$ \\
\hline \multicolumn{3}{|l|}{ Tid i Sverige ${ }^{b}$} \\
\hline Medel & $\begin{array}{l}-0.334 \\
(0.581)\end{array}$ & $\begin{array}{l}-0.303 \\
(0.555)\end{array}$ \\
\hline Längre & $\begin{array}{l}-0.389 \\
(0.854)\end{array}$ & $\begin{array}{l}-0.174 \\
(0.887)\end{array}$ \\
\hline \multicolumn{3}{|l|}{ Socioekonomisk klass: ${ }^{\mathrm{c}}$} \\
\hline Medelklass & & $\begin{array}{l}-0.282 \\
(1.150)\end{array}$ \\
\hline Arbetarklass & & $\begin{array}{l}-0.009 \\
(0.891)\end{array}$ \\
\hline Arbetslös & & $\begin{array}{l}0.650 \\
(0.996)\end{array}$ \\
\hline \multicolumn{3}{|l|}{$\begin{array}{l}\text { Kontrollvariabler: } \\
\text { Kön }^{\mathrm{d}}\end{array}$} \\
\hline Man & & $\begin{array}{l}1.123 \\
(0.666)\end{array}$ \\
\hline \multicolumn{3}{|l|}{ Familj $^{\mathrm{e}}$} \\
\hline $\mathrm{Ja}$ & & $\begin{array}{l}-0.457 \\
(0.665)\end{array}$ \\
\hline Konstant & $\begin{array}{l}4.087 * * * \\
(0.891)\end{array}$ & $\begin{array}{l}3.736 * * \\
(1.411)\end{array}$ \\
\hline $\mathrm{R}^{2}$ & 0.07 & 0.10 \\
\hline
\end{tabular}




\section{Diskussion och slutsatser}

En viktig utgångspunkt i denna studie har varit att eftersom elever är brukare av läroböcker är det följaktligen centralt att efterfråga deras åsikter om dem. Elever borde kunna ge viktig och intressant information som kan vara till nytta och glädje inte bara för dem som skriver läroböcker och förlagsredaktörer utan också för att ge lärare input om läroböckernas didaktiska effektivitet (Knecht \& Najvarová, 2010; Dargusch, Persaud \& Horsley, 2011).

Mot bakgrund av den pedagogiska och didaktiska relevansen av att studera attityder till innehåll och delaktighet vid val av läroböcker var det övergripande syftet med denna studie att undersöka relationen mellan humankapital (ålder, tid i Sverige, utbildning) och vuxna flyktingars attityder till innehåll i läroböcker och deras möjligheter att påverka val av läroböcker.

Denna studie tyder på att vuxna flyktingar har potentialer att komma med synpunkter på innehållet. Resultaten ger stöd åt humankapitalteorin med avseende på betydelsen av utbildningsår. Men resultaten ger inte stöd åt humankapitalteorin med avseende på betydelsen av ålder eller tid i Sverige på attityder till delaktighet och innehållet i läroboken. Detta indikeras av att ca 19 \% av variationen i attityder till delaktighet och $9 \%$ av variationen av attityder till innehållet kan förklaras utifrån utbildningsnivån på deltagarna. Resultatet har en tydlig didaktisk och pedagogisk signifikans. Teoretiskt bidrar resultaten dels till att bekräfta den växande forskningen om betydelsen av humankapitalfaktorer vid studiet av flyktingars lärande och integration, dels till den generella betydelsen av humankapitalteorin inom utbildningsvetenskaplig forskning (AdamutiTrache, Anisef, Sweet \& Walters, 2013; Sweetland, 1996).

Hur förhåller sig då mina resultat till den inledningsvis refererade forskningen om utbildning i svenska för vuxna invandrare?

Vi börjar med den första forskningsfrågan: "I vilken utsträckning tycker vuxna flyktingar att de får vara delaktiga vid val av läroböcker?” De högutbildade anser att de får vara med och bestämma över valet av läroböcker. De lågutbildade anser däremot att det är läraren som bestämmer. Resultaten är här i överensstämmelse med Franker (2007) som fann att de vuxna lågutbildade invandrarna inte tilläts vara delaktiga och Hvenekilde, Alver, Bergander, Lahaug och Midttun (1996) som fann att de vuxna deltagarna inte hade någon möjlighet att få förmedla sina förväntningar på alfabetiseringsläromedlen. Den andra forskningsfrågan är: "I vilken utsträckning tycker vuxna flyktingar att innehållet i läroböcker är barnsligt/tråkigt?” De lågutbildade anser i lägre grad än de högutbildade att läroböckerna är tråkiga/barnsliga. Här skiljer sig mina resultat från Frankers (2007).

I studien fanns en effekt av attityder till delaktighet vid val av lärobok. Attityden till delaktighet vid val av läroböcker skilde sig åt mellan elever som hade en yrkesbakgrund i övre medelklassyrken jämfört med elever med en bakgrund i arbetarklassyrken. Eleverna från övre medelklassyrken anser att de får bestäm- 
ma lika mycket som läraren medan elever från arbetarklassyrken anser att läraren för det mesta bestämmer. Emellertid fanns en osäkerhet i resultaten som innebär att effekten på 9 \% från testet av skillnader i medelvärden inte stod sig i regressionsanalysen och vi fick ingen signifikans. Resultaten bör därför tolkas med försiktighet. Här kan det dock vara på sin plats att påpeka att även om resultaten är osäkra (dvs. breda konfidensintervall och stora standardfel) så kan en effekt på 9 \% ha didaktisk och pedagogisk signifikans för lärare och läroboksförläggare även om den är osäker (Kirk, 1996).

Hur kan vi då förklara resultaten? En möjlig förklaring kan vara att de högutbildade har en viss vana att ställa krav på delaktighet. De förväntar sig helt enkelt att få vara med och bestämma när läroböcker väljs. Det kan medföra att de inte accepterar att inte få vara delaktiga. De högutbildade har mött många böcker under sin långa utbildning. De har således mycket att jämföra med och vill ha läroböcker som de finner är en kognitiv utmaning att ta itu med. Det kan innebära att de högutbildade är mer "kräsna" när det gäller innehållet i läroböcker än de lågutbildade. De lågutbildade har inte mött så många böcker och har därför inte så mycket att jämföra med. De kanske också i högre utsträckning än de högutbildade ser läraren som en auktoritet och därför tycker att det är tryggast att överlåta valet av lärobok åt läraren (jfr Storeng, 2001; Askeland, 2014). En annan möjlig förklaring kan vara att lärarna har högre förväntningar på de högutbildade och därför uppmuntras de att vara delaktiga i högre grad än de lågutbildade (Schweisfurth, 2011). En ytterligare möjlig förklaring kan vara att lärarna ser elevernas delaktighet som en process som just startat. Följaktligen har eleverna inte märkt så mycket av den ännu (Storeng, 2001). Här skulle en framtida studie kunna fånga upp processen genom att studera nyanlända elevers attityder över tid.

Ett viktigt bidrag med denna studie är att jag studerat vuxna flyktingars attityder till innehåll i läroböcker inom ramen för humankapitalteorin. Tidigare studier har genomgående efterfrågat lärares attityder till innehåll i läromedel och ingen större studie har efterfrågat vuxna nyanlända invandrares, inklusive analfabeters, attityder till innehållet i läromedel (Bueie, 2002; Skjelbred, Solstad \& Aamotsbakken, 2005; Aamotsbakken \& Skjelbred, 2010).

En begränsning med studien är att urvalet, 186 elever, fortfarande är litet och att det inte rör sig om ett slumpmässigt urval. Detta kan inverka på säkerheten rörande socioekonomisk klass. Effekten av socioekonomisk klass var i vissa fall statistiskt signifikant och i andra inte. Troligen skulle säkerheten ökats om urvalets storlek hade varit större då ett mått alltid blir mer precist ju fler deltagare som ingår i studien.

Antalet deltagare påverkar studiens förmåga att upptäcka statistiska effekter. Desto färre deltagare desto större är chansen för att regressionsanalysen inte upptäcker små till medelstora effekter (s.k. "Typ II fel”). Vi vet också från "the Law of Large Numbers" att chansen att stickprovets medelvärden och 
regressionskoefficienter närmar sig populationsvärdena ökar i takt med att stickprovets storlek ökar.

En andra begränsning är att studien inte kan kontrollera för påverkan av variabler som inte observerades i studien (t. ex. "begåvning”, "etnicitet”, “modersmål”). Icke observerade variabler kan korrelera med mätfelet, vilket leder till att regressionskoefficienterna under- eller överskatter den sanna effekten. För att kontrollera för icke observerade variabler hade studien behövt antingen en kontrollgrupp - nyanlända som inte deltog i SFI - eller paneldata. Konsekvensen är att studien inte kan identifiera några kausala effekter eftersom jag inte kan utesluta att en icke observerad variabel påverkar mätfelet hos de beroenden variablerna. Designbeslut blir därför en viktig fråga som framtida studier bör överväga.

En slutsats som kan dras utifrån denna studie är att utbildning var den centrala förklaringsvariabeln som hade störst förklaringskraft med avseende på elevernas attityder. En didaktisk och pedagogisk implikation av detta är att betydelsen av att låta eleverna vara delaktiga vid val av läromedel inte nog kan understrykas. Eftersom eleverna är brukare av läromedel så borde de i rimlighetens namn få vara delaktiga. En annan slutsats är att elevernas yrkesbakgrund i hemlandet (socioekonomisk klass) kan ha en betydande pedagogisk och didaktiskt effekt. Men denna effekt är mer osäker än effekten av utbildning.

\section{Referenser}

Adamuti-Trache, M., Anisef, P., Sweet, R. \& Walters, D. (2013). Enriching foreign qualifications through Canadian post-secondary education: Who participates and why? Journal of International Migration and Integration, 14(1), 139-156.

Alver, V. \& Dregelid, M. (2001). Er vi på rett vei nå? Opplæring for analfabeter i Norge. I K. Nauclér (red.), Symposium 2000. Ett andraspråksperspektiv på lärande (s. 258-276). Stockholm: Sigma förlag.

Askeland, O. (2014). Literacy og integrering: språkopplæring for minoritetsspråklege vaksne med liten skulebakgrunn i lys av kritisk pedagogikk. Mastersuppsats, Universitetet i Bergen.

Bueie, A. (2002). Lœrebokvalg - en formalisert og systematisk prosess? En undersøkelse av valg av lærebøker for norskfaget i den videregående skolen. Tønsberg: Høgskolen i Vestfold.

Dargusch, J., Persaud, N. \& Horsley, M. (2011). Judging the quality of educational materials. A research project on student voice. IARTEM e-Journal, 4(2), 45-62.

Franker, Q. (2007). Bildval i alfabetiseringsundervisning - en fråga om synsätt. Licentiatuppsats, Stockholm universitet.

Hilt, L. T. (2016). They don't know what it means to be a student: Inclusion and exclusion in the nexus between 'global' and 'local'. Policy Futures in Education, 14(6), 666-686.

Hvenekilde, A., Alver, V., Bergander, E., Lahaug, V. \& Midttun, K. (1996). Alfa og Omega. Om alfabetiseringsundervisning for voksne fra minoriteter. Oslo: Novus forlag. 
Justvik, N. M. (2012). Tradisjonalisme og faktaorientering blant historielærere? Utvelgelsesprosesser for læreverk i historie i videregående skole: En pilotundersøkelse. Acta Didactica Norge, 6(1), Art. 14.

Juuhl, G. K., Hontvedt, M. \& Skjelbred, D. (2010). Læremiddelforsking etter LK06: Eit kunnskapsoversyn. Tønsberg: Høgskolen i Vestfold.

Karlsson, A. (2006). En arbetsdag i skriftsamhället: Ett etnografiskt perspektiv på skriftanvändning i vanliga yrken (1. uppl.). Stockholm: Språkrådet.

Kirk, R. E. (1996). Practical significance: A concept whose time has come. Educational and Psychological Measurement, 56(5), 746-759.

Kjelsaas, L. (2011). Om å snakke samme språk. En studie av ansattes synspunkter på frafall fra norskopplering blant voksne innvandrere. Mastersuppsats, Universitet i Oslo.

Knecht, P. \& Najvarová, V. (2010). How do students rate textbooks? A review of research and ongoing challenges for textbook research and textbook production. Journal of Educational Media, Memory, and Society, 2(1), 1-16.

Lindberg, I. (2004). Andraspråksresan. Stockholm: Folkuniversitetet.

Lundberg, I. \& Reichenberg, M. (2009). Vad är lättläst? Härnösand: Specialpedagogiska skolmyndigheten.

Nilsson, A. \& Nyström, Ö. (2016). Flyktingkrisen och den svenska modellen. Lund: Celanders förlag.

Pollestad, A. S. (2015). Undervisningsmateriell og lese- og skrivepraksiser i den grunnleggende lese- og skriveopplæringen for voksne andrespråksinnlærere av norsk. Mastersuppsats, Universitet i Oslo.

Rambøll (2011). Brukerundersøkelse om norskoppleringen blant voksne innvandrere. Rambøll Rapport. Nedladdad från http://www.ramboll.no/ /media/images/rm/rm\%20no/pdf/publikasjoner/2011/brukerunder sokelse\%20i\%20norskopplaeringen.pdf

Reichenberg, M. (2013). Are "reader-friendly" texts always better?. IARTEM e-Journal, 5(2), 64-82.

Reichenberg, M. (2014). Predicting teachers' choice of teaching and learning materials: A survey study with Swedish teachers. IARTEM 6(2), 71-93.

Rong, X. L. \& Preissle, J. (2008). Educating immigrant students in the 21st century: What educators need to know. Thousand Oaks, CA: Sage-Corwin.

Rose, D. \& Harrison, E. (2007). The European socio-economic classification: A new social class schema for comparative European research. European Societies, 9(3), 459-490.

SCB (2014). STATIV. En longitudinell databas för integrationsstudier. Stockholm: Statistiska Centralbyrån.

Schweisfurth, M. (2011). Learner-centred education in developing country contexts: From solution to problem? International Journal of Educational Development, 31(5), 425-432.

Selander, S. \& Skjelbred, D. (2004). Pedagogiske tekster for kommunikasjon og læring. Oslo: Universitetsforlaget.

Skjelbred, D., Solstad, T. \& Aamotsbakken, B. (2005). Kartlegging av lceremidler og lœremiddelpraksis. Tønsberg: Høgskolen i Vestfold.

Skolverket (2012). Utbildning i svenska för invandrare. Kursplan och kommentarer. Stockholm: Fritzes.

Skolverket (2015). Statistik om utbildning i svenska för invandrare. Nedladdad 21. december 2016 från http://www.skolverket.se/statistik-och-utvardering/statistik-itabeller/utbildning-i-svenska-for-invandrare

Skaalvik S. (2004). Deltakerinnflytelse i voksenopplaring: en studie av norskopplaring for voksne innvandrere. Trondheim: Tapir Akademisk forlag. 
Šopova, J. (2007). Editorial. The UNESCO Courier, 10. Nedladdad från http://unesdoc.unesco.org/images/0019/001921/192180e.pdf

Storeng, M. (2001). Giving learners a chance: Learner-centredness in the reform of Namibian teaching. Stockholms Universitet Rapport nr. 56, Stockholms universitet.

Sweetland, S. R. (1996). Human capital theory: Foundations of a field of inquiry. Review of Educational Research, 66(3), 341-359.

Tarone, E., Bigelow, M. \& Hansen, K. (2009). Literacy and oracy in second language acquisition. Oxford: Oxford University Press.

United Nations (2015). Report of the Secretary-General on the implementation of Security Council resolutions 2139 (2014), 2165 (2014) and 2191(2014). United Nations Rapport S/2015/962. Nedladdad från http://www.un.org/en/ga/search/view doc.asp?symbol=S/2015/962

Vinogradov, P. \& Bigelow, M. (2010). Using oral language skills to build on the emerging literacy of adult English learners. CAELA Network Brief, August 2010. Nedladdad från http://files.eric.ed.gov/fulltext/ED540592.pdf

Aamotsbakken, B. \& Skjelbred, D. (2010). Lesing av fagtekster som grunnleggende ferdighet. Oslo: Novus.

\footnotetext{
${ }^{1}$ I en UNESCO-rapport uppskattas att det finns 774 miljoner vuxna som inte når upp till en miniminivå när det gäller att läsa, skriva och räkna (Šopova, 2007). Det innebär att en på fem vuxna inte är litterat och vidare att två tredjedelar av dessa är kvinnor (Tarone et al., 2009).

${ }^{2}$ Namnet är fiktivt.
} 